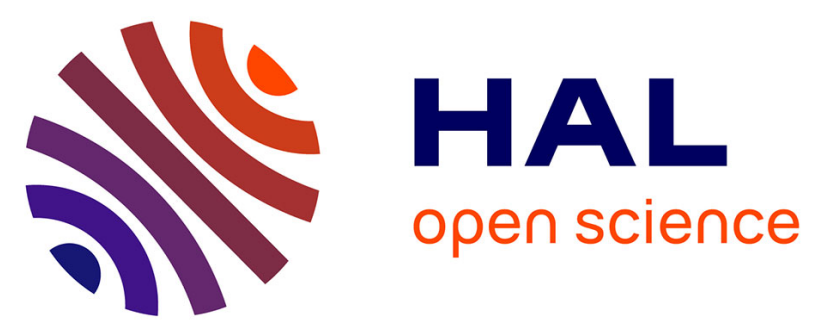

\title{
Effects of Self-Handicapping Strategies on Anxiety Before Athletic Performance
}

Guillaume R. Coudevylle, Kathleen Martin Ginis, Jean-Pierre Famose, Christophe Gernigon

\section{- To cite this version:}

Guillaume R. Coudevylle, Kathleen Martin Ginis, Jean-Pierre Famose, Christophe Gernigon. Effects of Self-Handicapping Strategies on Anxiety Before Athletic Performance. Sport Psychologist, 2008, 22 (3), pp.304-315. 10.1123/tsp.22.3.304 . hal-01343255

\section{HAL Id: hal-01343255 \\ https://hal.univ-antilles.fr/hal-01343255}

Submitted on 8 Jan 2018

HAL is a multi-disciplinary open access archive for the deposit and dissemination of scientific research documents, whether they are published or not. The documents may come from teaching and research institutions in France or abroad, or from public or private research centers.
L'archive ouverte pluridisciplinaire HAL, est destinée au dépôt et à la diffusion de documents scientifiques de niveau recherche, publiés ou non, émanant des établissements d'enseignement et de recherche français ou étrangers, des laboratoires publics ou privés. 
1 RUNNING HEAD: SELF-HANDICAPPING AND ANXIETY IN SPORT

2

Guillaume R. Coudevylle

Université de Montpellier 1, France

Kathleen A. Martin Ginis 


\section{Abstract}

The purpose of the present experiment was to examine whether the use of self-

3 handicapping strategies influences participants' anxiety levels prior to athletic performance.

4 Seventy-one competitive basketball players participated in the study. A repeated measures

5 design was utilized, such that state cognitive and somatic anxiety intensity and direction were

6 measured before and after participants were given the opportunity to self-handicap. Overall,

7 participants reported their cognitive anxiety to be more facilitating after they had the

8 opportunity to self-handicap. Thus, participants who were given the opportunity to self-

9 handicap (i.e., use claimed and behavioral self-handicaps), reported greater increases in

10 perceptions of cognitive anxiety as facilitating their performance. This study shows the

11 importance of looking at anxiety direction, and not just anxiety intensity, when examining

12 self-handicapping's effects on anxiety. Implications for sport psychologists are proposed.

14 Key words: Self-handicapping, Anxiety, Intensity, Direction, Sport 
3 phenomenon as "any action or choice of performance setting that enhances the opportunity to

4 externalize (or excuse) failure and to internalize (reasonably accept credit for) success" (p. 406).

5 Self-handicaps are used as an impression management strategy (see Kolditz \& Arkin, 1982;

6

\section{Effects of Self-handicapping Strategies on Anxiety Prior to Athletic Performance}

Self-handicapping was first described by Berglas and Jones (1978), who defined the

Prapavessis, Grove, \& Eklund, 2004) and provide a means for protecting or even enhancing one's self- and public image. Self-handicaps also blur the relationship between ability and performance.

A self-handicapping athlete who performs poorly can attribute failure to the performance

9 impediment rather than ability or competence, whereas the athlete who performs well creates the impression of being especially competent and talented, because success was achieved despite impediments (see Tice, 1991). Self-handicaps can be defined according to their manifestation. The two manifestations of self-handicaps are behavioral and claimed self-handicaps (see Hirt, Deppe, \& Gordon, 1991; Leary \& Shepperd, 1986). Examples of behavioral handicaps include alcohol consumption (e.g., Bordini, Tucker, Vuchinich, \& Rudd, 1986), the selection of unattainable goals (Greenberg, 1985) or the lack of practice (e.g., Harris \& Snyder, 1986; Tice \& Baumeister, 1990). Examples of claimed self-handicaps include declarations that one is very anxious (e.g., Smith, Snyder, \& Handelsman, 1982) or experiencing various physical and psychological symptoms (e.g., Smith, Snyder, \& Perkins, 1983; Snyder \& Smith, 1982). Self-handicapping in sport has been conceptualised as both a trait (e.g., Ommundsen, 2001, 2004; Pulford, Johnson, \& Awaida, 2005) and a state phenomenon (e.g., Elliot, Cury, Fryer, \& Huguet, 2006; Martin \& Brawley, 2002; Standage, Treasure, Hooper, \& Kuczka, 2007). Individual studies of self-handicapping have used either or both of these approaches (e.g., Carron, Prapavessis, \& Grove, 1994; Greenlees, Jones, Holder, \& Thelwell, 2006; Ryska, Yin, \& Cooley, 1998). The trait approach is typically concerned with whether dispositional assessments of self- 
1 handicapping tendencies - such as scores on the trait Self-Handicapping Scale (Jones \&

2 Rhodewalt, 1982) - are related to sport-relevant psychological and behavioral variables. For

3 example, studies have shown that dispositional self-handicapping tendencies are negatively

4 correlated with precompetitive mood states (Prapavessis \& Grove, 1994), perceptions of group

5 cohesion (Carron et al., 1994), practice effort (Rhodewalt, Saltzman, \& Wittmer, 1984), and

6 global self-esteem (Prapavessis \& Grove, 1998). Other studies have shown that dispositional self-

7 handicapping tendencies are positively correlated with impression management concerns

8 (Hudson, Williams, \& Stacey, 1998), a high level of optimal experience during competitive

9 performances (Bailis, 2001), and the use of emotion-orientated coping strategies (Prapavessis,

10 Grove, Maddison, \& Zillmann, 2003).

11 Unfortunately, the validity of the Self-Handicapping Scale in the sport domain has been

12 heavily criticized (Martin \& Brawley, 1999), thus undermining the utility of a dispositional

13 approach. As such, several investigators have utilized a situational approach to study self-

14 handicapping, and have focused on identifying factors that might be associated with athletes' use

15 of self-handicaps immediately prior to an evaluated event. Within the sport domain, studies have

16 shown that situational use of self-handicaps is associated with performance-avoidance goals

17 (Elliot et al., 2006), low self-efficacy and low self-esteem (Martin \& Brawley, 2002). Therefore,

18 the present study utilized a situational approach to examine the relationship between situational

19 manifestations of self-handicapping immediately prior to a basketball task, and state sport

20 competition anxiety.

21 Self-handicapping and Anxiety

22 Two approaches have been used to study the relationship between self-handicapping and

23 sport competition anxiety. With the first approach, researchers have examined anxiety as a

24 possible determinant of self-handicapping. These studies have shown that trait competition 
1 anxiety is positively correlated with situational manifestations of claimed self-handicapping

2 (Ferrand, Champely, \& Brunel, 2005) and that state competition anxiety is positively correlated

3 with trait measures of self-handicapping (Prapavessis et al., 2003). The second approach has been

4 to examine whether the use of self-handicaps can decrease state sport competition anxiety.

5 Theorists have suggested that self-handicapping can decrease performance anxiety by reducing

6 pressure to perform well (see Leary \& Shepperd, 1986; Snyder, 1990). In the one study to use

7 this approach, Ryska and colleagues (1998) hypothesized that among youth athletes who scored

8 high on a trait measure of self-handicapping, those who used more claimed self-handicaps prior

9 to a sport competition would report less sport competition anxiety than those who used fewer

10 claimed self-handicaps. This hypothesis was not supported.

11 However, Ryska and colleagues (1998) utilised a correlational design whereby athletes

12 completed the anxiety measure just before they competed. To properly test the effects of self-

13 handicapping on anxiety, it would be better to measure anxiety before and after athletes were

14 given the opportunity to self-handicap. Using a pre-test/post-test design it would be possible to

15 determine if athletes felt less anxiety after self-handicapping. In addition, the null findings of

16 Ryska and colleagues could be explained by the fact that they did not analyse the anxiety

17 direction (i.e., how people perceived their anxiety as being favourable for the performance vs.

18 unfavourable for the performance). Indeed, Jones and Swain (1992) showed that simply

19 measuring anxiety intensity does not indicate if anxiety is perceived as unfavourable or

20 favourable to performance (i.e., interpretation of this anxiety). Although there was no relationship

21 between the intensity of cognitive and somatic anxiety and the use of self-handicapping,

22 participants could have interpreted both anxiety states as being more facilitative to performance

23 than they did before self-handicapping. 
With the limitations of Ryska and colleagues (1998) in mind, the purpose of the present

2 experiment was to examine whether the use of self-handicapping strategies influences

3 participants' anxiety levels prior to athletic performance. Specifically, we examined if

4 participants felt less anxiety (i.e., cognitive and somatic) after the use of claimed and behavioral

5 self-handicaps. Additionally, because anxiety is not always perceived in a negative way (Jones \&

6 Swain, 1992), we also examined whether self-handicapping was associated with how participants

7 perceived their anxiety. It was predicted that participants would feel less anxiety (i.e., cognitive

8 and somatic) and perceive anxiety to be more facilitating for their performance (i.e., cognitive

9 and somatic) after the use of self-handicapping strategies.

Method

\section{Participants}

12 Seventy-one competitive basketball players, 31 men $(M$ age $=20.5$ years; $S D=3.5)$ and

1340 women $(M$ age $=19.3$ years; $S D=2.6)$, participated in the study. All players competed at the

14 French regional level — a sufficiently competitive level to ensure that participants would be

15 personally invested in the experimental task and its outcome. Note that the data from 56

16 participants represent a secondary analysis of data currently under review (Coudevylle, Martin

17 Ginis, Gernigon, \& Famose, 2008).

18 Measure

19 State Cognitive and Somatic Anxiety. State anxiety was measured with a French version of the

20 Competitive State Anxiety Inventory - 2 (CSAI-2; Martens, Vealey, \& Burton, 1990) -- l'Echelle

21 d'Etat d'Anxiété à la Compétition (EEAC; Cury, Sarrazin, Peres, \& Famose, 1999). This

22 questionnaire consists of 7-items measuring cognitive anxiety and 7-items measuring somatic

23 anxiety. For each item, participants indicated the extent to which they were currently

24 experiencing each anxiety symptom, using a Likert scale ranging from 1 (not at all) to 4 
1 (completely). Because athletes' interpretation of anxiety symptoms has been identified as an

2 important dimension for consideration, we also measured the direction of state anxiety using a

3 protocol developed by Jones and Swain (1992). After each CSAI-2 item, participants indicated

4 whether their level of anxiety (i.e., anxiety intensity) would have a favourable or unfavourable

5 effect on their upcoming performance. Responses were made on a Likert scale ranging from -3

6 (very unfavourable) to +3 (very favourable). To avoid the possibility of participants claiming

7 anxiety symptoms as a form of claimed self-handicap, the anxiety scale was presented

8 confidentially and participants were told that only the researcher would see their responses.

9 Claimed Self-handicapping. A state measure similar to that used by Martin and Brawley (Study

102 2, 2002) was used to measure claimed self-handicapping. Yet whereas Martin and Brawley's

11 scale consisted of just 7 possible impediments, our scale consisted of 13 impediments that

12 athletes may use as self-handicaps such as: "I am feeling tired," "I have personal concerns in this

13 moment," "I am not feeling well mentally," "I am not sufficiently prepared for the test," "I am

14 feeling well," and "I am approaching the test under the best conditions." (Note that the last two

15 items were reverse-scored.) The impediments were those most frequently cited by athletes in

16 Carron and colleagues' studies of self-handicapping in sport (Carron et al., 1994; Hausenblas \&

17 Carron, 1996). In addition, participants were presented with a fourteenth, open-ended item that

18 gave the opportunity to list any other potential impediments to their performance. For each item,

19 participants indicated whether the impediment was present (yes/no), and the extent to which each

20 impediment would interfere with their performance (i.e., perceived impact), using a scale ranging

21 from 0 (not at all) to 6 (extremely). A claimed self-handicapping score was calculated by

22 averaging the impact scores for all impediments that were identified as "present." Higher scores

23 were indicative of greater claims of performance impediments, and as such, greater self-

24 handicapping. 
When athletes use claimed self-handicaps, they cite only one or two performance

2 impediments. It is unusual for an athlete to cite several claimed self-handicaps, probably because

3 only a single self-handicapping claim is needed to protect an athlete's image, and the use of

4 multiple self-handicaps could have considerable self-presentational liabilities. Given that athletes

5 do not typically endorse multiple self-handicaps, it is inappropriate to calculate an internal

6 consistency index for this type of self-handicapping measure (i.e., because athletes are not

7 expected to respond similarly to all of the scale items). Construct validity for this approach to

8 measuring self-handicapping has been demonstrated by studies that have shown significant

9 correlations between the claimed impact of performance impediments and theoretically

10 meaningful constructs such as self-esteem, self-presentational efficacy, and performance self-

11 efficacy (Coudevylle, Martin Ginis, \& Famose, in press; Martin \& Brawley, 2002).

12 Behavioral Self-handicapping. According to Prapavessis and colleagues (2004), a lack of

13 preparatory effort preceding a test constitutes an index of behavioral self-handicapping within the

14 context of sports participation. Thus, for the purpose of the present experiment, behavioral self-

15 handicapping was operationalized as the number of preparatory shots taken during a warm-up

16 period immediately prior to performance the experimental task. A short practice time has been

17 identified as a self-handicapping strategy in previous studies because it is detrimental to

18 performance (see Harris \& Snyder, 1986; Tice, 1991). No participant had previous experience

19 with the experimental task.

20 Studies have provided evidence of the validity of practice time and effort as an index of

21 behavioral self-handicapping. For example, Rhodewalt and colleagues (1984) showed that high

22 self-handicapping swimmers withheld practice effort prior to competitions compared to low self-

23 handicapping swimmers. In addition, other studies have shown that the amount of time spent 
1 warming up/practicing is related to self-handicapping (e.g., Deppe \& Harackiewicz, 1996; Tice \&

2 Baumeister, 1990).

3 Performance. Performance was scored by counting the number of successful shots and passes

4 completed on an obstacle course. Specifically, the performance consisted of 2 free-throws, 1 lay-

5 up, 1 jump shot and 1 three-point shot. The participants scored 1 point for each. Then, for each

6 repetition of the course, participants scored 2 points when they dribbled the ball between three

7 cones, while bouncing the ball between the legs and passing it behind the back. They lost 1 point

8 for each technical error. Performance scores could range from 0 to 11.

9 The Experimental Task

10 The task consisted of completing three repetitions of an obstacle course laid out on a

11 standard basketball court. The test began with the completion of two free-throws followed by

12 running to mid-court, and then turning around backwards and performing a backward defensive

13 shuffle to the end of the court. Then, the participant picked up a basketball and dribbled it to mid-

14 court. At mid-court, the participant dribbled the ball between three cones, while bouncing the ball

15 between the legs and passing it behind the back. The participant then continued to the basket and

16 attempted a lay-up. After the lay-up, the participant repeated the entire course again and finished

17 with a jump shot. The course was repeated a third time, finishing with a three-point shot. This is

18 the same task as reported in Coudevylle and colleagues (in press).

19 Procedure

20 To test our hypotheses, anxiety was measured before and after participants were given the

21 opportunity to self-handicap. To maximize the likelihood of self-handicapping, an experimental

22 situation was created in which factors that are known to elicit self-handicapping (for a review, see

23 Prapavessis et al., 2004; Self, 1990) were made salient. Specifically, the testing situation

24 emphasized public performance, an emphasis on results, social comparisons of one's 
1 performance with others, and public awareness of the use of self-handicaps. Participants

2 performed the test in the presence of spectators, coaches and other players, were told that their

3 test results would be used to identify the best and worst players in the region, and that their scores

4 would be compared with their teammates' scores (see Coudevylle et al., in press).

5 After hearing and reading this information, participants completed baseline measures of

6 anxiety intensity and direction. Then, they completed the measure of claimed self-handicapping.

7 To make sure that all participants realized that the questionnaire provided an opportunity to use

8 claimed self-handicaps, participants were told:

9 "The following questionnaire is intended to assess your general actual state in order to

10 comment on your results today. It will allow those that will evaluate your competence (the

11 experimenter, your trainer, the other players, the spectators) to consider your current personal

12 situation when authenticating your results and comparing them with those of the other

13 participants. Your responses to this questionnaire will be made public along with your results

14 so that those who evaluate your performance will be better able to evaluate your competence."

15 Thus, the true purpose of the scale was masked in order to obtain honest replies.

16 After completing the claimed self-handicapping measure, the experimenter explained

17 (orally and through written instructions) the warm-up procedure. Specifically, participants were

18 told that they could have as many practice shots as they desired to warm-up. To make sure that all

19 participants realized that the number of preparatory shots could serve as a behavioral self-

20 handicap, the experimenter indicated that the number of preparatory shots could provide an

21 explanation for a good or bad performance on the test. He also reminded players that a good

22 warm-up is essential to a good performance. Therefore, participants knew that the lack of practice

23 before the test could be detrimental to their performance (see Harris \& Snyder, 1986; Tice, 1991).

24 This was a reasonable claim, given that no participant had previous experience with the 
1 experimental task. As no participant had previously performed the experimental task, one can

2 assume that a warm-up would be essential to successful performance of the task. After hearing

3 and reading this information, participants completed the second measures of anxiety intensity and

4 direction. These measures were administered before rather than after the warm-up (adapted from

5 Elliot et al., 2006; Hirt, Deppe, \& Gordon, 1991). This process was used in order to avoid a break

6 between the warm-up and the test, and participants losing the benefits of their preparation.

7 Participants then warmed-up in two periods. The first warm-up period (15 minutes) consisted of a

8 quick run, stretching and repetitions of the course, but without taking any practice shots. The

9 second warm-up period consisted of taking practice shots. Although participants performed the

10 experiment in groups, they warmed up individually (i.e., no other players were on the court at the

11 same time, but other players were present as observers). The experimenter counted the number of

12 preparatory shots taken as the measure of behavioral self-handicapping. After the participant

13 indicated to the experimenter that she/he was finished warming up, the experimental task

14 proceeded. Once the participant had completed the task, the participant was debriefed regarding

15 the true purpose of the study. Additionally, the first author provided each team with a lecture and

16 proposed a discussion on self-handicapping and its consequences.

Results

Descriptive statistics for the self-handicapping measures are shown in Table 1. On

19 average, men cited 4.67 performance impediments were present and women indicated the

20 presence of 3.95 performance impediments. The mean impact of these impediments was 3.85 for

21 men and 3.83 for women, indicating that participants perceived the impediments would have a

22 moderate impact on their performance. With regards to behavioral self-handicapping, men took

23 an average of 21.64 practice shots and women took an average of 15.15 shots. Descriptive

24 statistics for the anxiety measures are shown in Table 2. Because there were sex differences on 
1 several of the dependent measures, sex was subsequently treated as an independent variable in the

2 following analyses.

3 To determine if participants felt less anxiety (i.e., cognitive and somatic) and perceived

4 anxiety to be more facilitating after the opportunity to self-handicap, separate 2 (gender) $\times 2$

5 (time) repeated measures ANOVAs were conducted on cognitive and somatic anxiety intensity

6 and direction. The ANOVA for cognitive anxiety intensity showed a main effect for gender $[F(1$,

$769)=5.04, p<.05]$, but not for time, and no interaction effects $(p s>.05)$. The ANOVA for

8 cognitive anxiety direction showed a main effect for gender $[F(1,69)=7.92, p<.01]$, and a main

9 effect for time $[F(1,69)=5.91, p<.05]$, but no interaction effects $(p>.05)$. As shown in Table

102 , women perceived more cognitive anxiety than men and perceived their anxiety to be less

11 facilitating. Overall, participants reported their cognitive anxiety to be more facilitating after they

12 had the opportunity to self-handicap. The ANOVAs for somatic anxiety intensity and direction

13 showed no main effect for gender, or time, and no interaction effects (all $p s>.05$ ). Thus,

14 participants who were given the opportunity to self-handicap (i.e., claimed and behavioral self-

15 handicapping) reported greater increases in perceptions of cognitive anxiety as facilitating their

16 performance.

Discussion

18 The purpose of the present experiment was to determine if participants felt less anxiety

19 and perceived anxiety to be more facilitating after the use of claimed and behavioral self-

20 handicaps. The results provided minimal support for our hypotheses. Claimed self-handicapping

21 did not have any effect on the intensity of cognitive or somatic anxiety, and behavioral self-

22 handicapping did not have any effect on the intensity of somatic anxiety. However, participants 
1 who engaged in more behavioral self-handicapping (i.e., took fewer preparatory shots), reported

2 greater increases in perceptions of cognitive anxiety as facilitating their performance.

Our failure to find an effect of self-handicapping on anxiety intensity is contrary to

4 theorizing (Leary \& Shepperd, 1986; Snyder, 1990) but is consistent with the null findings

5 reported by Ryska and colleagues (1998). These results could be explained by the fact that the

6 measure of anxiety intensity does not indicate if this anxiety is perceived as unfavourable or

7 favourable to performance (Jones \& Swain, 1992). Indeed, although there was no difference on

8 the intensity of cognitive and somatic anxiety after the opportunity to self-handicap, participants

9 interpreted their cognitive anxiety states as being more facilitative to performance than before

10 self-handicapping. Our results showed that to examine the influence of self-handicapping

11 strategies on anxiety, it is necessary to analyse the direction of this anxiety. It seems that the

12 effects of self-handicapping on anxiety are reflected in improvements in athletes' perceptions of

13 their anxiety--self-handicapping may help athletes feel more ready and optimally aroused for the

14 upcoming challenges of an evaluated performance. This interpretation is consistent with Bailis'

15 (2001) finding that athletes who scored higher on a dispositional measure of self-handicapping

16 reported higher levels of optimal experience during competitive performances than athletes who

17 were less prone to self-handicapping. Our study is the first to demonstrate the effects of self-

18 handicapping on anxiety direction and our results speak to the importance of looking beyond

19 anxiety intensity (Jones \& Swain, 1992) when examining self-handicapping's effects on anxiety.

20 Self-handicapping affected the perceived beneficence of cognitive, but not somatic

21 anxiety. There are at least two plausible explanations for this finding. First, as shown in Table 1,

22 athletes already had fairly positive perceptions of their somatic anxiety at baseline. Thus, there

23 may have been little space for improvement in anxiety perceptions after self-handicapping. A

24 second possibility reflects differences in factors that underlie cognitive and somatic anxiety. 
1 Cognitive anxiety--like self-handicapping--stems from worries about evaluative aspects of an

2 upcoming performance. In contrast, somatic anxiety stems from conditioned responses to aspects

3 of competition, such as the presence of an audience (Martens et al., 1990; Jones, 1995). As self-

4 presentational concerns regarding an upcoming sports performance have been shown to be more

5 strongly correlated with cognitive than somatic sport competition anxiety (Bray, Martin, \&

6 Widmeyer, 2000; Wilson \& Eklund, 1998), it makes sense that a strategy designed to allay self-

7 presentational concerns (i.e., self-handicapping), would have greater effects on cognitive than

8 somatic elements of anxiety.

9 Another interesting observation was that the analyses showed a main effect for gender on

10 cognitive anxiety (intensity and direction), but no interactive effects with self-handicapping were

11 observed. Gender did not moderate the effects of self-handicapping on anxiety intensity or

12 direction. Although there may be differences in the extent to which male and female athletes use

13 self-handicaps (Hausenblas \& Carron, 1996; Hirt, McCrea, \& Kimble, 2000), our data suggest

14 that the effects of self-handicapping on anxiety do not differ as a function of gender.

15 Despite the contributions of our study to understanding the effects of self-handicapping on

16 anxiety, a couple of limitations warrant mention. First, although the internal validity of our study

17 was enhanced by the use of a controlled basketball task, it is not known whether our findings

18 would generalize to real-world basketball games. However, given that athletes are more likely to

19 use self-handicaps when they perceive an event as highly important (Rhodewalt et al., 1984), we

20 suspect that the findings of the present study would be even more pronounced during actual game

21 situations. A second limitation is that we do not know if all participants considered the warm-up

22 to be equally important. A recommendation for future research is that investigators pre-measure

23 athletes' perceptions of the importance of warming up, and their perceived ideal duration of a

24 warm-up. And finally, as with all self-handicapping studies, it is impossible to know if athletes' 
1 claims of performance impediments and their reductions in practice time were purely motivated

2 by the self-handicapper's desire for self-enhancement or protection. In future research, it may be

3 helpful to conduct post-experimental interviews in order to better understand athletes' motives

4 for these behaviours.

$5 \quad$ From an applied perspective, our results suggest that coaches and sport psychologists

6 need to be prudent when intervening with self-handicapping athletes in order to allow for their

7 psychological protection. Although our results showed that self-handicapping helped to change

8 the direction of anxiety, it is not known if there were negative effects of self-handicapping on

9 performance. Future research is needed to examine whether the anxiolytic benefits of self-

10 handicaps are overshadowed by their performance detriments. 
2 Bailis, D. (2001). Benefits of self-handicapping in sport: A field study of university athletes. Canadian Journal of Behavioural Science, 33, 213-223.

4 Berglas, S., \& Jones, E. E. (1978). Drug choice as a self-handicapping strategy in response to non contingent success. Journal of Personality and Social Psychology, 36, 405-417.

Bordini, E. J., Tucker, J. A., \& Vuchinich, R. E., \& Rudd, E. J. (1986). Alcohol consumption as a self-handicapping strategy in women. Journal of Abnormal Psychology, 95, 346-349.

Bray, S. R., Martin, K. A., \& Widmeyer, W. N. (2000). The relationship between evaluative concerns and sport competition state anxiety among youth skiers. Journal of Sports Sciences, 18, 353-361.

11 Carron, A. V., Prapavessis, H., \& Grove, J. R. (1994). Group effects and self-handicapping. Journal of Sport \& Exercise Psychology, 16, 246-257.

13 Coudevylle, G., Martin Ginis, K, \& Famose, J-P. (in press). Determinants of self-handicapping strategies in sport and their effects on athletic performance. Social Behavior and Personality, An International Journal.

Coudevylle, G., Martin Ginis, K., Gernigon, C., \& Famose, J-P. (2008). An experimental investigation of determinants and consequences of self-handicapping strategies across motivational climates. Manuscript under revision.

Cury, F., Sarrazin, P., Peres, C., \& Famose, J-P. (1999). Mesurer l'anxiété du sportif en compétition : présentation de l'échelle d'état d'anxiété en compétition (EEAC). In Ch. Le Scanff et J-P. Famose (Eds.), La gestion du stress. Paris : Editions Revue EPS nº43.

Deppe, R. K., \& Harackiewicz, J. M. (1996). Self-handicapping and intrinsic motivation: Buffering intrinsic motivation from the threat of failure. Journal of Personality and Social Psychology, 70, 868-876. 
1 Elliot, A. J., Cury, F., Fryer, J. W., \& Huguet, P. (2006). Achievement goals, self-handicapping, and performance attainment: A mediational analysis. Journal of Sport \& Exercise Psychology, 28, 344-361.

4 Ferrand, C., Champely, S., \& Brunel, P. C. (2005). Relations between female students' personality traits and reported handicaps to rhythmic gymnastics performance. Psychological Reports, 96, 361-373.

7 Greenberg, J. (1985). Unattainable goal choice as a self-handicapping strategy. Journal of Applied Social Psychology, 15, 140-152.

9 Greenlees, I., Jones, S., Holder T., \& Thelwell, R. (2006). The effects of self-handicapping on attributions and perceived judo competence. Journal of Sports Sciences, 24, 273-280.

11 Harris, R. N., \& Snyder, C. R. (1986). The role of uncertain self-esteem in self-handicapping. Journal of Personality and Social Psychology, 51, 451-458.

13 Hausenblas, H. A., \& Carron, A. V. (1996). Group cohesion and self-handicapping in female and male athletes. Journal of Sport and Exercise Psychology, 18, 132-143.

15 Hirt, E. R., Deppe, R. K., \& Gordon, L. J. (1991). Self-reported versus behavioral selfhandicapping: Empirical evidence for a theoretical distinction. Journal of Personality and Social Psychology, 61, 981-991.

Hirt, E. R., McCrea, S. M., \& Kimble, C. E. (2000). Public self-focus and sex differences in behavioral self-handicapping: Does increasing self-threat still make it "just a man's game?" Personality \& Social Psychology Bulletin, 26, 1131-1141.

21 Hudson, J., Williams, M., \& Stacey, P. (1998). Impression management and self-handicapping in middle-distance runners. Journal of Sport Sciences, 16, 390-391.

23 Jones, G. (1995). More than just a game: Research developments and issues in competitive state anxiety in sport. British Journal of Psychology, 86, 449-478. 
1 Jones, E. E., \& Rhodewalt, F. (1982). The Self-Handicapping Scale. Unpublished manuscript, 2 Department of Psychology, Princeton University.

3 Jones, G. \& Swain, A. (1992). Intensity and direction as dimensions of competitive state anxiety 4 and relationships with competitiveness. Perceptual and Motor Skills, 74, 467-472.

5 Kolditz, T. A. \& Arkin, R. M. (1982). An impression management interpretation of the self6 handicapping strategy. Journal of Personality and Social Psychology, 43, 492-502.

7 Leary, M. R., \& Shepperd, J. A. (1986). Behavioral self-handicapping vs. self-reported handicaps: A conceptual note. Journal of Personality and Social Psychology, 51, 12651268.

10 Martens, R., Vealey, R. S., \& Burton, D. (1990). Competitive anxiety in sport. Champaign, IL: $11 \quad$ Human Kinetics Publishers.

12 Martin, K. A., Brawley, L. R. (1999). Is the self-handicapping scale reliable in non-academic 13 achievement domains? Personality and Individual Differences, 27, 901-911.

14 Martin, K. A., \& Brawley, L. R. (2002). Self-handicapping in physical achievement settings: The contributions of self-esteem and self-efficacy. Self and Identity, 1, 337-351.

Ommundsen, $Y$. (2001). Self-handicapping strategies in physical education classes: The influence of implicit theories of the nature of ability and achievement goal orientations. Psychology of Sport and Exercise, 2, 139-156.

19 Ommundsen, Y. (2004). Self-handicapping related to task and performance-approach and avoidance goals in physical education. Journal of Applied Sport Psychology, 16, 183-197.

Prapavessis, H., \& Grove, J. R. (1994). Personality variables as antecedents of precompetitive mood state temporal patterning. International Journal of Sport Psychology, 25, 347-365.

23 Prapavessis, H., \& Grove, J. R. (1998). Self-handicapping and self-esteem. Journal of Applied Sport Psychology, 10, 175-184. 
1 Prapavessis, H., Grove, J. R., \& Eklund, R. C. (2004). Self-presentational issues in competition and sport. Journal of Applied Sport Psychology, 16, 19-40.

3 Prapavessis, H., Grove, J. R., Maddison, R., \& Zillmann, N. (2003). Self-handicapping tendencies, coping, and anxiety responses among athletes. Psychology of Sport and Exercise, 4, 357-375.

6 Pulford, B. D., Johnson, A., \& Awaida, M. (2005). A cross-cultural study of predictors of selfhandicapping in university students. Personality and Individual Differences, 39, 727-737.

Rhodewalt, F., Saltzman, A. T., \& Wittmer, J. (1984). Self-handicapping among competitive athletes: The role of practice in self-esteem protection. Basic and Applied Social Psychology, 5, 197-209.

11 Ryska, T. A., Yin, Z. N., \& Cooley, D. (1998). Effects of trait and situational self-handicapping on competitive anxiety among athletes. Current Psychology, 17, 48-56.

13 Self, E. A. (1990). Situational influences on self-handicapping. In R. L. Higgins, C. R. Snyder et S. Berglas (Eds.), Self-handicapping: The paradox that isn't? (pp. 37-68). New York:

Smith, T. W., Snyder, C. R., \& Handelsman, M. M. (1982). On the self-serving function of an academic wooden leg: Test Anxiety as a self-handicapping strategy. Journal of Personality and Social Psychology, 42, 314-321.

19 Smith, T. W., Snyder, C. R., \& Perkins, S. C. (1983). The self-serving function of hypochondriacal complaints: Physical symptoms as self-handicapping strategies. Journal

22 Snyder, C. R. (1990). Self-handicapping processes and sequelae: On the taking of a psychological dive. In R. L. Higgins, C. R. Snyder et S. Berglas (Eds.), Self-handicapping: The paradox that isn't? (pp. 107-150). New York: Plenum Press. 
1 Snyder, C. R., \& Smith, T. W. (1982). Symptoms as self-handicapping strategies: The virtues of old wine in a new bottle. In G. Weary (Eds.), Integrations of Clinical and Social Psychology (pp. 104-127). New York: Oxford University Press.

4 Standage, M., Treasure, D. C., Hooper, K., \& Kuczka, K. (2007). Self-handicapping in school physical education: The influence of the motivational climate. British Journal of Educational Psychology, 77, 81-99.

7 Tice, D. M. (1991). Esteem protection or enhancement? Self-handicapping motives and attributions differ by trait self-esteem. Journal of Personality and Social Psychology, 60, 711-725.

10 Tice, D. M., \& Baumeister, R. F. (1990). Self-esteem, self-handicapping, and self-presentation:

11 The strategy of inadequate practice. Journal of Personality, 58, 443-464.

12 Wilson, P., \& Eklund, R. C. (1998). The relationship between competitive anxiety and self13 presentational concerns. Journal of Sport \& Exercise Psychology, 20, 81-97. 
1 Table 1.

2 Descriptive Statistics for Self-handicapping Strategies and Performance

\begin{tabular}{|c|c|c|c|c|c|c|c|c|c|c|}
\hline & \multicolumn{2}{|c|}{$\begin{array}{c}\text { Claimed } \\
\text { Self-handicap }\end{array}$} & \multicolumn{2}{|c|}{ Impact } & \multicolumn{2}{|c|}{$\begin{array}{l}\text { Mean } \\
\text { Impact }\end{array}$} & \multicolumn{2}{|c|}{$\begin{array}{c}\text { Behavioral } \\
\text { Self-handicapping }\end{array}$} & \multicolumn{2}{|c|}{ Performance } \\
\hline & $M$ & $S D$ & $M$ & $S D$ & $M$ & $S D$ & $M$ & $S D$ & $M$ & $S D$ \\
\hline & & & & & & & & & & \\
\hline Total & 4.26 & 2.16 & 15.73 & 7.50 & 3.84 & 1.48 & 17.98 & 12.72 & 6.80 & 1.48 \\
\hline Men & 4.67 & 2.15 & 16.77 & 7.06 & 3.85 & 1.50 & 21.64 & 16.62 & 6.77 & 1.54 \\
\hline Women & 3.95 & 2.14 & 14.92 & 7.82 & 3.83 & 1.48 & 15.15 & 7.68 & 6.82 & 1.46 \\
\hline & & & & & & & & & & \\
\hline
\end{tabular}

12 
1 Table 2.

2 Means and Standard Deviations for the Measures of Anxiety

3

4

5

6 Cognitive Anxiety

7

8

9

10 Cognitive Anxiety Direction*

11

12

13

14 Somatic Anxiety

Men

16

Woman

17

18 Somatic Anxiety Direction

Men

9.94

7.30

10.33

12.22

8.87

19

11.03

7.65

10.91

20

Woman

9.10

7.00

10.80

11.00
9.37

8.19

7.86

1.85

9.60

2.78

3.02

2.61

$21 \quad$ * main effect for time, $p<.05$

$22+$ main effect for sex, $p<.05$

$23{ }^{++}$main effect for sex, $p<.01$ 